\title{
Application of Hydroxamic Modified Calix[6]arene for Selective Extraction of Uranium (VI)
}

\author{
Yan LIN ${ }^{1, a}$, Jing-Song WANG ${ }^{2, b,}$, Jie ZHOU ${ }^{3, c}$, Feng-Rong FANG ${ }^{4, d}$ \\ ${ }^{1}$ Key Laboratory of Pollution Control and Resource Reuse of Hunan, University of South China, \\ Hengyang 421001, China \\ ${ }^{2}$ Key Discipline Laboratory of National Defense for Biotechnology in Uranium Mining and \\ Hydrometallurgy, University of South China, Hengyang 421001, China \\ a315687381@qq.com, bxhwjs@163.com, czjtq1019@163.com, d416268266@qq.com \\ ${ }^{*}$ Corresponding author
}

Keywords: Calix[6]arene, Hydroxamic derivatives, Uranium, Extraction.

\begin{abstract}
Calix[6]arene hydroxamic derivatives were synthesized by two steps using calix[6]arene, ethyl bromoacetate and hydroxylamine hydrochloride as the main raw materials, and were characterized by infrared spectroscopy. The extraction of U(VI) by calix[6]arene and its hydroxamic derivatives on various experimental conditions were studied. The extraction results showed that $\mathrm{pH}$ played an important role in the extraction system. Maximum extraction was observed at a $\mathrm{pH}$ of 5.0 within $20 \mathrm{~min}$, and the dynamic extraction model corresponded to a pseudo-second order model.
\end{abstract}

\section{Introduction}

In the last decade, an increasing amount of attention has been paid to calixarenes and their derivatives due to their unique molecular structure and simple one-pot synthesis for supramolecular chemistry[1]. Calixarene is a unique macromolecular compound with a cavity structure[2], and many studies have investigated the modification of its upper and lower edge with functional groups[3]. The calixarene derivatives have been applied in many areas, including molecular recognition, enzyme mimics, chemical sensors, and molecular assembly as well as optoelectronic and nanomaterials.

The application of calixarenes modified by heteroatom-containing groups for the extraction of heavy metals and transitional metals has been extensively studied due to their high complexation and recognition abilities[4]. Recent studies have indicated that functional groups containing nitrogen efficiently improve the ability of calixarene for the selective recognition of metal ions. Such functional groups include amidogen, acylamino, pyridine and Schiff base. The larger cavity in calix[6]arenes and calix[8] arenes with six and eight aromatic rings are more suitable for anchoring binding groups than calix[4]arenes. Uranium is an important radioactive element, and excessive amounts of uranium are released into the environment through activities associated with the nuclear industry and mining. Our main objective in this paper was to investigate the extraction of U(VI) by calix[6]arene hydroxamic derivative from an aqueous solution.

\section{Experimental}

\section{Main Instruments and Chemicals}

A PHS-3C precision pH meter, an electronic balance, a 2000 ultraviolet spectrophotometer, an EQUINOX 55 Fourier transform infrared (FTIR) spectrometer, a JJ-1 electric mixer, an HZP-C air bath oscillator, a DF205 electrothermal blowing dry box and an H.H.S11-4R Electro Thermostatic Water Bath were used in this study. $\mathrm{U}_{3} \mathrm{O}_{8}$ was provided by the Key Discipline Laboratory of National Defense for Biotechnology in Uranium Mining and Hydrometallurgy at the University of South China. 


\section{Synthesis of Calix[6]arene and Calix[6]arene Hydroxamic Derivatives}

Calix[6]arene was synthesized according to a previously published protocol[5,6]. The structure of calix[6]arene is shown in Fig. 1. The calix[6] arene hydroxamic derivatives were synthesized based on previously reported procedures[7,8]. And the structure of calix[6]arene hydroxamic derivatives is shown in Fig. 2.

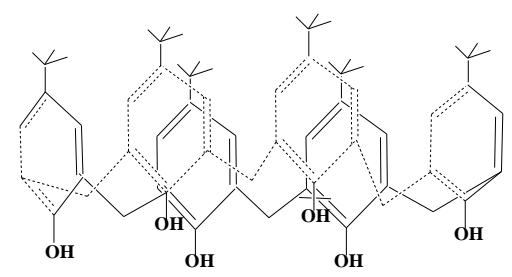

Fig. 1 Structure of calix[6]arene.

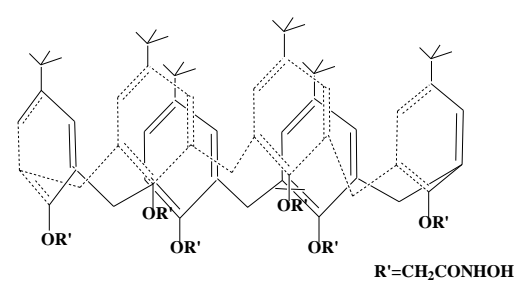

Fig. 2 Structure of the calix[6]arene hydroxamic derivative.

\section{Extraction of Uranium by Calix[6]arene Hydroxamic Derivatives}

$20 \mathrm{~mL}$ of an aqueous solution of $\mathrm{U}(\mathrm{VI})$ ions at different original concentrations (i.e., 0.021 $\mathrm{mmol} \cdot \mathrm{L}^{-1}, 0.042 \mathrm{mmol} \cdot \mathrm{L}^{-1}$ and $0.084 \mathrm{mmol} \cdot \mathrm{L}^{-1}$ ) and $20 \mathrm{~mL}$ of a calix[6]arene hydroxamic derivative chloroform bulk solution at different original concentrations (i.e., $0.21 \mathrm{mmol} \cdot \mathrm{L}^{-1}, 0.42 \mathrm{mmol} \cdot \mathrm{L}^{-1}$, $0.84 \mathrm{mmol} \cdot \mathrm{L}^{-1}$ and $1.68 \mathrm{mmol} \cdot \mathrm{L}^{-1}$ ) was added to Erlenmeyer flasks, respectively. The results of the solution $\mathrm{pH}$, calix[6]arene hydroxamic derivative concentration and contact time on the extraction capacity of the calix[6]arene hydroxamic derivatives for U(VI) were investigated. After the flasks were agitated on an orbital shaker $(220 \mathrm{rpm})$ for a certain period of time, the concentration of U(VI) in aqueous phase was determined as previously described[9].

The percent removal was calculated using the following equations:

$$
\text { Percentage removal }(\%)=\frac{\left(C_{0}-C\right)}{C_{0}} \times 100 .
$$

where $\mathrm{C}_{0}$ and $\mathrm{C}$ are the concentrations of the uranium(VI) in the original solution $\left(\mathrm{mg} \cdot \mathrm{L}^{-1}\right)$ before and after extraction, respectively.

\section{Results and Discussion}

\section{Infrared Spectra Analysis}

The infrared spectra of calix[6]arene and its acetic ether and hydroxamic derivatives are shown in Fig. 3. In the IR spectra of calix[6]arene, the C-O of the phenol was seen at $1217.08 \mathrm{~cm}^{-1}$, and the vibrational peaks at $1602.85 \mathrm{~cm}^{-1}, 1485.19 \mathrm{~cm}^{-1}$ and $1460.11 \mathrm{~cm}^{-1}$ were due to the aromatic skeleton. The $\mathrm{C}-\mathrm{H}$ of the methyl group $\left(\mathrm{CH}_{3^{-}}\right)$was observed at $2962.66 \mathrm{~cm}^{-1}$ and $2870.08 \mathrm{~cm}^{-1}$. The $\mathrm{CH}_{2^{-}}$is observed at $1485.19 \mathrm{~cm}^{-1}$. The bending vibration peak at $1396.07 \mathrm{~cm}^{-1}$ and $1361.74 \mathrm{~cm}^{-1}$ are due to the $\mathrm{C}-\mathrm{H}$ of symmetrical. The infrared spectra corresponding to the benzene ring, phenolic hydroxyl group and symmetrical confirmed the existence of calix[6]arene. In comparison to the IR spectra of calix[6]arene, the ethyl acetate derivatives exhibited a new vibrational peak at $1300 \mathrm{~cm}^{-1}$, which corresponds to the $\mathrm{C}-\mathrm{O}-\mathrm{C}$ vibrational peak from the aromatic ester. In comparison to the acetic ether derivatives, the hydroxamic derivatives exhibited $-\mathrm{OH}$ of hydroxamic at $3300 \mathrm{~cm}^{-1}$ and a $\mathrm{C}=\mathrm{N}$ of 
hydroxamic at $1620 \mathrm{~cm}^{-1}$ in the infrared spectra. The infrared spectra confirmed the structure of the calix[6]arene hydroxamic derivatives.

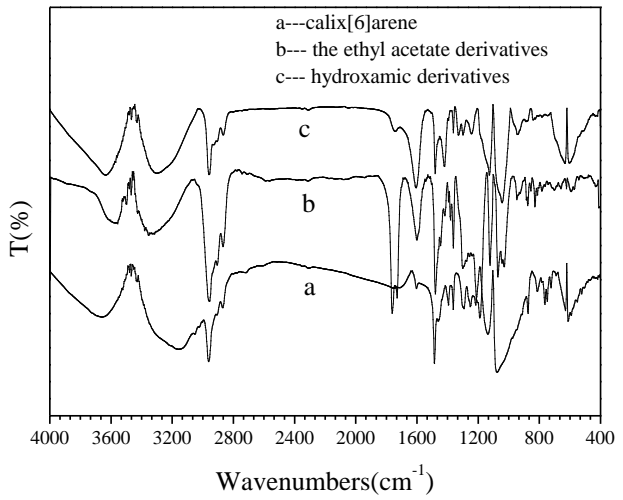

Fig. 3 IR spectra of calix[6]arene and its acetic ether and hydroxamic derivatives.

\section{Effect of the Solution pH}

The solution $\mathrm{pH}$ plays an important role in the extraction of U(VI) from an aqueous solution. Both the speciation of $\mathrm{U}(\mathrm{VI})$ in an aqueous solution and the binding sites present on the surface of the calix[6]arene hydroxamic derivatives are influenced by $\mathrm{pH}$. Experiments were performed at different $\mathrm{pH}$ values (2.0-6.0) at $25^{\circ} \mathrm{C}$. Extracted $\mathrm{U}(\mathrm{VI})(\%)$ as a function of $\mathrm{pH}$ is shown in Fig. 4.

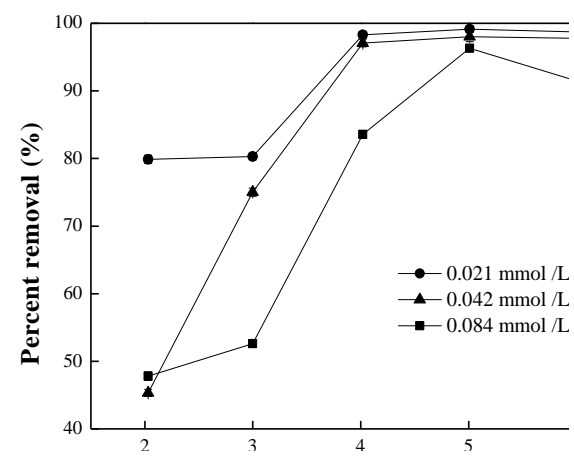

Fig. 4 Extraction of $\mathrm{U}(\mathrm{VI})$ at different $\mathrm{pH}$ values. Conditions: initial $\mathrm{U}(\mathrm{VI})$ concentration, 0.021 mmol L ${ }^{-1}, 0.042 \mathrm{mmol} \mathrm{L}^{-1}, 0.084 \mathrm{mmol} \mathrm{L}^{-1}$; contact time, $20 \mathrm{~min}$; temperature, $25^{\circ} \mathrm{C}$; calix[6]arene hydroxamic derivatives concentration, $0.42 \mathrm{mmolL}^{-1}$.

The maximum percent removal of $\mathrm{U}(\mathrm{VI})$ was obtained at a $\mathrm{pH}$ of 5.0, and the minimum percent removal of U(VI) was observed at a $\mathrm{pH}$ of 2.0. The removal of U(VI) increased as the $\mathrm{pH}$ increased in the range of 2.0-4.0 but nearly remained constant in the range of 4.0-5.0. The observed decrease in the extraction capacity at $\mathrm{pH}>6.0$ is attributed to the precipitation of uranium. When the solution $\mathrm{pH}$ is less than 2.0, $\mathrm{U}(\mathrm{VI})$ exists predominately in the form of $\mathrm{UO}_{2}{ }^{2+}$. A high concentration of $\mathrm{H}^{+}$and $\mathrm{H}_{3} \mathrm{O}^{+}$ compete with U(VI) for the coordination site, which results in a decrease in the extraction of U(VI) at low $\mathrm{pH}$ values. Optimum extraction at $\mathrm{pH} 5.0$ may due to the presence of ligands, such as carboxyl and hydroxyl groups on the calix[6]arene hydroxamic derivatives. The decrease in the uptake of U(VI) at higher $\mathrm{pH}$ values may be due to the formation of uranyl complexes, such as $\mathrm{UO}_{2} \mathrm{OH}^{+}$, $\left(\mathrm{UO}_{2}\right)_{2}(\mathrm{OH})^{2+}$ and $\left(\mathrm{UO}_{2}\right)_{3}(\mathrm{OH})_{5}{ }^{+}$. The optimum $\mathrm{pH}$ was determined to be 5.0, and all of the subsequent experiments were conducted at this $\mathrm{pH}$ value.

\section{Effect of Original Concentration of Calix[6]arene Hydroxamic Derivatives}

The experiments were performed by varying the concentration of the calix[6]arene hydroxamic derivatives from $0.21 \mathrm{mmol} \cdot \mathrm{L}^{-1}$ to $0.42 \mathrm{mmol} \cdot \mathrm{L}^{-1}, 0.84 \mathrm{mmol} \cdot \mathrm{L}^{-1}$ and $1.26 \mathrm{mmol} \cdot \mathrm{L}^{-1}$. The percent removal and extraction capacity of the calix[6]arene hydroxamic derivatives for U(VI) at different extractant concentrations are presented in Fig. 5. 


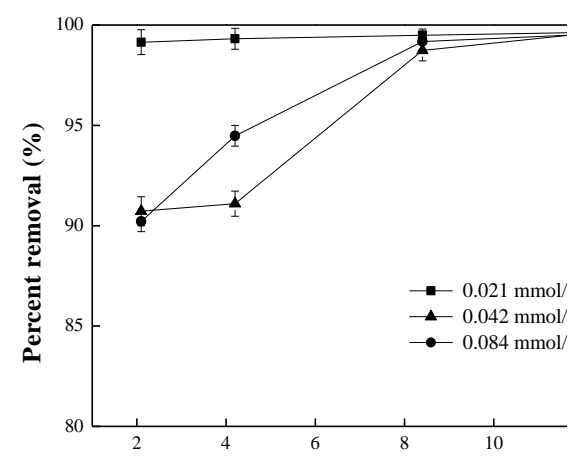

Fig. 5 Extraction of U(VI) at different concentrations of calix[6]arene hydroxamic derivatives (0.21 $\left.\mathrm{mmolL}^{-1}, 0.42 \mathrm{mmolL}^{-1}, 0.84 \mathrm{mmolL}^{-1}, 1.26 \mathrm{mmolL}^{-1}\right)$. Conditions: initial U (VI) concentration, $0.021 \mathrm{mmol} \mathrm{L}^{-1}, 0.042 \mathrm{mmol} \mathrm{L}^{-1}, 0.084 \mathrm{mmol} \mathrm{L}^{-1}$; contact time, $20 \mathrm{~min}$; temperature, $25^{\circ} \mathrm{C}$; initial $\mathrm{pH}$, 5.0 .

The percent removal increased as the extractant concentrations increased for concentrations less than $0.84 \mathrm{mmol} \cdot \mathrm{L}^{-1}$. The maximum removal efficiency was obtained at a calix[6]arene hydroxamic derivative concentration of $0.84 \mathrm{mmol} \cdot \mathrm{L}^{-1}$ and remained constant at higher concentrations. This trend is due to the partial aggregation of the extractant at higher concentrations, which results in fewer binding sites for $\mathrm{U}(\mathrm{VI})$ ions during the extraction. In addition, the results indicated that the percent removal of $\mathrm{U}(\mathrm{VI})$ at an original $\mathrm{U}(\mathrm{VI})$ concentration $0.021 \mathrm{mmol} \cdot \mathrm{L}^{-1}$ was higher than that an original $\mathrm{U}(\mathrm{VI})$ concentration of $0.042 \mathrm{mmol} \cdot \mathrm{L}^{-1}$ and $0.084 \mathrm{mmol} \cdot \mathrm{L}^{-1}$. Therefore, as the concentration of $\mathrm{U}(\mathrm{VI})$ increased, fewer coordination sites were available to the extractant.

\section{Effect of Contact Time}

The percent removal and extraction capacity of the calix[6]arene hydroxamic derivatives for U(VI) at different contact times is shown in Fig. 6. The results indicated that the percent removal of U(VI) by calix[6]arene hydroxamic derivatives increased from $30.7 \%$ to $99.7 \%$ when the contact time was varied from $5 \mathrm{~min}$ to $30 \mathrm{~min}$. The extraction process was very fast after $15 \mathrm{~min}$. In addition, extraction equilibrium was established within $20 \mathrm{~min}$. It was also observed that the extraction slowed down in the later stages because the available surface vacant sites decreased over time.

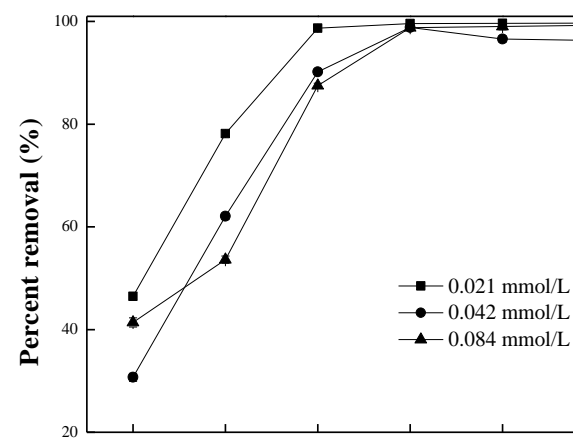

Fig. 6 Extraction of U(VI) as a function of contact time. Conditions: initial U(VI) concentration, $0.021 \mathrm{mmolL}^{-1}, 0.042 \mathrm{mmolL}^{-1}, 0.084 \mathrm{mmolL}^{-1}$; temperature, $25^{\circ} \mathrm{C}$; initial $\mathrm{pH}, 5.0$; calix[6]arene hydroxamic derivative concentration, $0.42 \mathrm{mmolL}^{-1}$.

\section{Extraction Kinetics}

The linear form of the pseudo-first order model and the pseudo-second order model for the extraction of $\mathrm{U}(\mathrm{VI})$ at various original $\mathrm{U}(\mathrm{VI})$ concentrations were used to investigate the extraction characteristic. The correlation coefficients $\left(\mathrm{R}^{2}\right)$ for the linear plots using the pseudo-first order model ranged from 0.936 to 0.943 . While the correlation coefficients for the linear plots from the 
pseudo-second order model ranged from 0.990 to 0.994 . This result suggests that the pseudo-second order model could be adapted to describe this process because it fitted more accurately to the experimental data. The kinetic constants of this model are shown in (Table 1).

Tab. 1. Kinetic parameters obtained from the Lagrangian models for the extraction of U(VI) by calix[6]arene hydroxamic derivatives. (initial U(VI) concentration, $0.021 \mathrm{mmol} \cdot \mathrm{L}^{-1}\left(5 \mathrm{mg} \cdot \mathrm{L}^{-1}\right), 0.042$ $\mathrm{mmol} \cdot \mathrm{L}^{-1}\left(10 \mathrm{mg} \cdot \mathrm{L}^{-1}\right), 0.084 \mathrm{mmol} \cdot \mathrm{L}^{-1}\left(20 \mathrm{mg} \cdot \mathrm{L}^{-1}\right) ; \mathrm{pH}$ value, 5.0; contact time, $0,5,10,15,20,25$, and $30 \mathrm{~min}$; temperature, $25^{\circ} \mathrm{C}$; calix[6]arene hydroxamic derivative concentration, $0.42 \mathrm{mmol} \cdot \mathrm{L}^{-1}$ )

\begin{tabular}{ccccccc}
\hline & $\mathrm{C}_{0}\left(\mathrm{mg} \cdot \mathrm{L}^{-1}\right)$ & \multicolumn{3}{c}{ Pseudo-first order } & \multicolumn{2}{c}{ Pseudo-second order } \\
& $\mathrm{k}_{1}\left(\mathrm{~min}^{-1}\right)$ & $\mathrm{q}_{\mathrm{e}}\left(\mathrm{mgg}^{-1}\right)$ & $\mathrm{R}^{2}$ & $\begin{array}{c}\mathrm{k}_{2}\left(\mathrm{gmg}^{-1}\right. \\
\left.\mathrm{min}^{-1}\right)\end{array}$ & $\mathrm{q}_{\mathrm{e}}\left(\mathrm{mgg}^{-1}\right)$ & $\mathrm{R}^{2}$ \\
\hline 5 & 0.2475 & 10.4682 & 0.936 & 0.1801 & 10.2987 & 0.994 \\
10 & 0.1394 & 18.2839 & 0.940 & 0.1118 & 21.6920 & 0.993 \\
20 & 0.2159 & 61.6950 & 0.943 & 0.0943 & 47.3934 & 0.990 \\
\hline
\end{tabular}

\section{Summary}

These results indicate that U(VI) ions can be efficiently extracted by calix[6]arene hydroxamic derivatives. Extraction of U(VI) was determined to be more effective at $\mathrm{pH} 4.0 \sim 6.0$, and the optimal extraction was observed at an original $\mathrm{pH}$ of 5.0. The results from the kinetic study indicated that the pseudo-second order model was more appropriate for describing the extraction process.

\section{Acknowledgments}

The Corresponding author is Dr Jingsong Wang. This research was supported by China National Natural Science Foundation (Nos. 21177053 and 11175081), the Innovation Project of the Key Discipline in Hunan Province (12K091) and the Construct Program of Innovative Team in USC (NHCXTD07) and the Graduate Students Innovation Experiment Project (2014XCX15). The authors thank Professor DING Dexin (Key Discipline Laboratory of National Defense for Biotechnology in Uranium Mining and Hydrometallurgy, the University of South China) for his constructive advice and kind help.

\section{References}

[1]Z. Asfari, V. Bohmer, J. Harrowfield, J. Vicens, and M. Saadioui, Calixarenes 2001, Dordrecht, Springer Netherlands, 2002.

[2]M Tabakci and M Yilmaz, Sorption characteristics of $\mathrm{Cu}$ (II ) ions onto silica gel-immobilized calix[4]arene polymer in aqueous solutions: Batch and column studies, J. Hazard. Mater.151(2008) 331-338.

[3]S. Sayin and M. Yilmaz, Preparation and uranyl ion extraction studies of calix[4]arene-based magnetite nanoparticles, Desalination. 276(2011) 328-335.

[4]P. D. Beer, J. P. Martin, and M. G. Drew, Calix[4]arene cryptand and new 1,3-bis-pyridyl,-bipyridyl and -alkylthioether calix[4]arenes designed to coordinate transition metal cations, Tetrahedron.48 (1992) 9917-9928.

[5]D. A. Casteel, and S. P. Peri, Steric and electronic effects in the aryl phosphate to arylphosphonate rearrangement, Synthesis. 09(1991) 691-693.

[6]C. D. Gutsche, B. Dhawan, K. H. No, and R. Muthukrishnan, Calixarenes. 4. The synthesis, characterization, and properties of the calixarenes from p-tert-butylphenol, J. Chem. Soc. Am. 103(1981) 3782-3792. 
[7]E. A. Shokova, and V. V. Kovalev, Thiacalixarenes-A new class of synthetic receptors, J. Org. Chem. Russ. 39(2003) 1-28.

[8]Y. Jiang, B. Zhao, X. Zhou, and L. Zhou, Flotation of diaspore and aluminosilicate minerals applying novel carboxyl hydroxamic acids as collector, Hydrometallurgy.104(2010) 112-118.

[9]J. Wang, X. Hu, J. Wang, Z. Bao, S. Xie, and J. Yang, The tolerance of Rhizopus arrihizus to U(VI) and biosorption behavior of U(VI) onto R. Arrihizus, J. Biochem. Eng. 51(2010)19-23. 